22. Weiler T, Bashir R, Anderson LVB, et al. Identical mutation in patients with limb girdle muscular dystrophy type $2 \mathrm{~B}$ or Miyoshi myopathy suggests a role for modifier gene(s). Hum Mol Genet 1999;8:871-877.

23. Anderson LVB, Davison K, Moss JA, et al. Dysferlin is a plasma membrane protein and is expressed early in human development. Hum Mol Genet 1999;8:855-861.

24. Argov Z, Sadeh M, Mazor K, et al. Dysferlin-related muscular dystrophy in Libyan Jews: clinical and genetic features. Brain 2000;123:1229-1237.

25. Bashir R, Britton S, Strachan T, et al. A gene related to Caenorhabditis elegans spermatogenesis factor fer-1 is mutated in limb-girdle type 2B. Nat Genet 1998;20:37-42.

26. Anderson LVB, Davison K, Moss JA, et al. Characterisation of monoclonal antibodies to calpain-3 and protein expression in muscle from patients with limb girdle muscular dystrophy type 2A. Am J Pathol 1998;153:1169-1179.

27. Angelini C, Fanin M, Freda MP, et al. The clinical spectrum of sarcoglycanopathies. Neurology 1999;52:176-179.

28. Duggan DJ, Gorospe JR, Fanin M, et al. Mutations in the sarcoglycan genes in patients with myopathy. N Engl J Med $1997 ; 336: 618-624$.

29. Hoffman EP. Counting muscular dystrophies in the postmolecular census. J Neurol Sci. 1999;164:3-6.

30. Bushby K, Anderson LVB, Pollitt C, et al. Abnormal merosin in adults. A new form of late onset muscular dystrophy not linked to chromosome 6q2. Brain 1998;121:581-588.

31. Anderson LVB, Davison K. Multiplex Western blotting system for the analysis of muscular dystrophy proteins. Am J Pathol 1999;154:1017-1022.

\title{
Neuro/mages
}
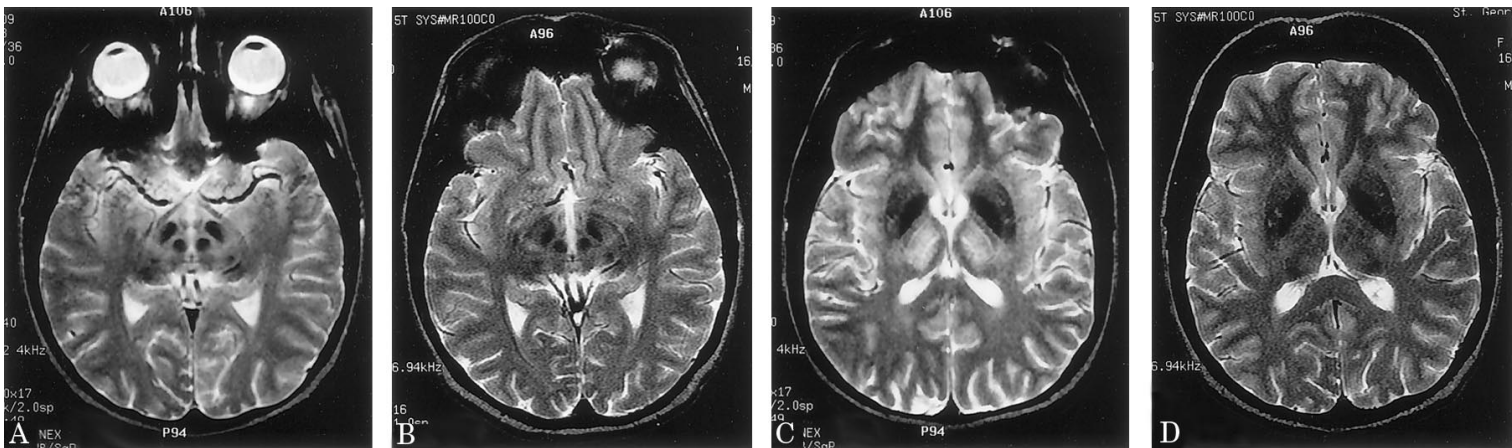

Figure. T2-weighted MR images. The initial scans at the level of the midbrain (A) and thalamus (C) are shown; (B) and (D) show corresponding images 1 year later.

\section{Disappearing "face of the giant panda"}

Alessandro Stefano Zagami, MD, FRACP, Peter Michael Boers, MBBS, FRACP, Sydney, Australia

A 28-year-old woman had been diagnosed with hepatic Wilson's disease at age 11 years. After a period of noncompliance with treatment she presented with a 12-month history of progressive upper limb and head tremor. On examination, she had titubation, dysarthria, and a resting upper limb tremor with a significant postural and action component. An MRI scan of the brain showed changes characteristic of Wilson's disease, including the "face of the giant panda" sign in the midbrain (figure, $\mathrm{A})^{1}$ and highintensity lesions in both thalami (figure, C). ${ }^{2}$ The patient improved, both clinically and radiologically (see figure, B and D), while taking an increased dose of D-penicillamine and pyridoxine. The T2 high-intensity lesions seen in the brainstem and thalamus in Wilson's disease are postulated to be secondary to edema or gliosis, and have been reported to disappear or attenuate following successful treatment of neurologic Wilson's disease. ${ }^{2}$ Accentuation of the normal low intensity of the red nuclei and substantia nigra by the surrounding abnormal high-intensity signal in the midbrain tegmentum results in the "face of the giant panda" sign, said to be characteristic of Wilson's disease. ${ }^{1}$ This particular midbrain abnormality has not previously been shown to disappear with successful treatment, as in the case reported here.

1. Hitoshi S, Iwata M, Yoshikawa K. Mid-brain pathology of Wilson's disease: MRI analysis of three cases. J Neurol Neurosurg Psychiatry 1991; $54: 624-626$

2. Roh JK, Lee TG, Wie BA, Lee SB, Park SH, Chang KH. Initial and follow-up brain MRI findings and correlation with the clinical course in Wilson's disease. Neurology 1994;44:1064-1068. 


\section{Neurology}

Disappearing "face of the giant panda"

Alessandro Stefano Zagami and Peter Michael Boers

Neurology 2001;56;665

DOI 10.1212/WNL.56.5.665

\section{This information is current as of March 13, 2001}

\section{Updated Information \&} Services

References

Citations

Permissions \& Licensing

Reprints including high resolution figures, can be found at: http://n.neurology.org/content/56/5/665.full

This article cites 2 articles, 2 of which you can access for free at: http://n.neurology.org/content/56/5/665.full\#ref-list-1

This article has been cited by 2 HighWire-hosted articles: http://n.neurology.org/content/56/5/665.full\#\#otherarticles

Information about reproducing this article in parts (figures,tables) or in its entirety can be found online at:

http://www.neurology.org/about/about_the_journal\#permissions

Information about ordering reprints can be found online:

http://n.neurology.org/subscribers/advertise

Neurology ${ }^{\circledR}$ is the official journal of the American Academy of Neurology. Published continuously since 1951, it is now a weekly with 48 issues per year. Copyright . All rights reserved. Print ISSN: 0028-3878. Online ISSN: 1526-632X.

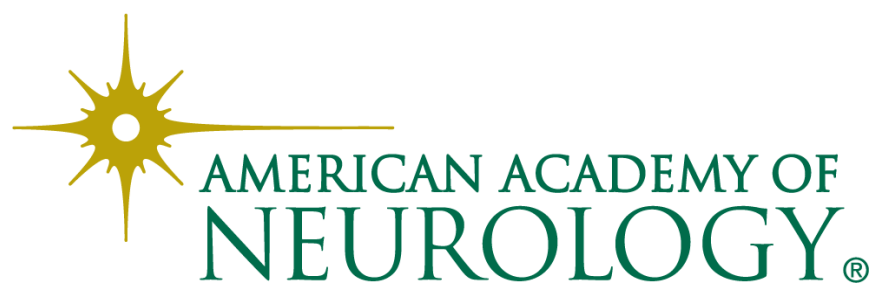

